\title{
Identification of a novel disease-associated variant in the BRCA1 3'UTR that introduces a functional miR-103 target site
}

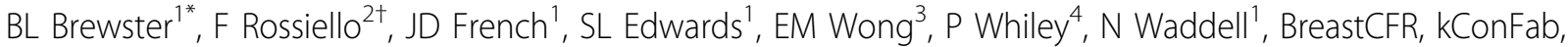 \\ $X$ Chen $^{5}$, B Bove ${ }^{5}$, AB Spurdle ${ }^{4}$, P Radice ${ }^{2}$, AK Godwin ${ }^{5}$, MC Southey ${ }^{3}$, MA Brown ${ }^{1 \dagger}$, P Peterlongo ${ }^{2 \dagger}$ \\ From Familial Aspects of Cancer 2011 Research and Practice: A combined meeting of kConFab, Australian \\ Breast Cancer Family Study, Australian Colorectal Cancer Family Study, Australian Ovarian Cancer Study, \\ Family Cancer Clinics of Australia and New Zealand and kConFab \\ Kingscliff, Australia. 23-26 August 2011
}

Mutations in the breast cancer susceptibility genes, $B R C A 1$ and $B R C A 2$, represent the majority of the known familial breast cancer risk, yet account for only $20 \%$ of the total risk. As $B R C A 1$ is a large gene, genetic screening of high-risk individuals is limited to the coding regions and intron-exon boundaries, which precludes the identification of mutations in non-coding and untranslated (UTR) regions. Although mutations within 3'UTRs have been identified in many genes and are known to influence cancer susceptibility through the disruption or creation of protein and microRNA binding regions, mutation analysis of the BRCA1 3'UTR to date has been very limited. In this study, we screened the $B R C A 1$ 3'UTR for potential regulatory mutations. Using a large cohort of $1,585 B R C A$-mutation negative, breast cancer cases, we identified seventeen novel BRCA1 3'UTR variants, eight of which were identified in breast cancer cases and absent in a large panel of cancer-free controls. Four of these variants, c. ${ }^{*} 58 \mathrm{C}>\mathrm{T}$, c. "528G $>$ C, c. ${ }^{*} 718 \mathrm{~A}>\mathrm{G}$, and c. ${ }^{*} 1271 \mathrm{~T}>\mathrm{C}$, significantly reduced 3'UTR associated regulatory activity, as measured by reporter assays using MDA-MB-231 breast cancer cells. In addition, three BRCA1 3'UTR variants, c."718A>G, c. "800T $>C$ and c."1340_42TGTdel, were predicted to create new miRNA binding sites. Of these, c."1340_42TGTdel showed a significant reduction $(25 \%, \mathrm{p}=0.0007)$ in luciferase activity when co-expressed with the predicted targeting miRNA, miR-103 in MCF-7 cells. This is the most comprehensive set of BRCA1 3'UTR variants published to date

\footnotetext{
† Contributed equally

'School of Chemistry and Molecular Biosciences, The University of

Queensland, Brisbane, Australia

Full list of author information is available at the end of the article
}

and highlights the importance of cataloguing 3'UTR variants for functional analyses and cancer risk association.

\section{Author details}

'School of Chemistry and Molecular Biosciences, The University of

Queensland, Brisbane, Australia. ${ }^{2}$ IFOM, Fondazione Istituto FIRC di Oncologia Molecolare, Via Adamello 16, 20139 Milan, Italy. ${ }^{3}$ Department of Pathology, The University of Melbourne, Melbourne, Australia. ${ }^{4}$ Queensland Institute of Medical Research, Brisbane, Australia; 5Fox Chase Cancer Center,

Philadelphia, PA, USA. ${ }^{5}$ Department of Pathology and Laboratory Medicine, University of Kansas Medical Center, Kansas City, KS, USA.

Published: 12 April 2012

doi:10.1186/1897-4287-10-S2-A88

Cite this article as: Brewster et al.: Identification of a novel diseaseassociated variant in the BRCA1 3'UTR that introduces a functional miR103 target site. Hereditary Cancer in Clinical Practice 2012 10(Suppl 2):A88.

Submit your next manuscript to BioMed Central and take full advantage of:

- Convenient online submission

- Thorough peer review

- No space constraints or color figure charges

- Immediate publication on acceptance

- Inclusion in PubMed, CAS, Scopus and Google Scholar

- Research which is freely available for redistribution

Submit your manuscript at www.biomedcentral.com/submit
() Biomed Central

\section{Ciomed Central}

